\title{
Academic Subject Guides: A Case Study of Use at San José State University
}

\section{Shannon M. Staley}

\begin{abstract}
Subject guides are lists of resources created to assist students with their research needs. While academic librarians ascribe great importance to subject guide development, it is difficult to tell whether students find them useful. A review of the literature reveals a lack of user-centered data in this area. This study investigates students' use of subject guides in three areas of study-Nursing, Journalism \& Mass Communications, and Organization \& Management. Results indicate that students who have received library instruction tend to use subject guides more frequently and find them useful.
\end{abstract}

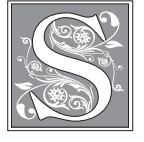

tevens, Canfield, and Gardner define a subject guide as a "kind of map to the resources of the library; it is an information locator for the library user whose search for recorded materials on a subject of interest is just beginning." 1 Academic librarians view subject guides - also called research guides, pathfinders, electronic library guides, and webliographies-as a critical resource in helping students get started on their research in a particular subject area. The literature establishes that librarians ascribe much importance to subject guides, not only as research aids for the campus community, but also as instructional, reference, and collection development tools for themselves. ${ }^{2}$

However, it is often difficult to tell whether students and faculty find subject guides useful. Web site usability testing often yields inconclusive results because the test sample is not representative of the actual campus population. Also, testing conditions do not accurately reflect users' actual information-seeking environment. Even Web log statistics, at best, are vague indicators of use since it is uncertain whether the total number of hits reflects students' or librarians' use. These statistics have become particularly problematic at San José State University's King Library, where academic and public librarians both rely on the use of subject guides to provide service to the campus community, making it impossible to extract student use data.

San José State is a Carnegie classified master's university that grants bachelor's and master's degrees in 134 areas of study, which are supported by a number of library services including course-integrated library instruction, hands-on workshops and Web-based subject guides. Subject 
guide content is managed by a databasedriven content management system using ColdFusion and Microsoft SQL. With this system in place, access to online databases-a popular library resource-are categorized by discipline and linked to corresponding subject guides in the hope that students using them will also notice other resources available through the subject guide.

In addition to the mandatory list of library databases relevant for each subject area, other pages of resources within the guides can be crafted to the needs of different academic programs on campus. For example, librarians can create subjectspecific annotations for resources in their area of expertise, the content of pages can be broken into subheadings of choice, and each guide contains a promotional box that can be populated with miscellaneous information such as a librarian's office hours, discipline-related library events, or notice of a new library resource. Librarians are also able to link from their subject guides to supplemental course materials maintained on the campus server. The system was deliberately set up to offer librarians flexibility in customizing guides to particular subject areas while at the same time retaining the same interface and navigational elements from one guide to the next. The flexibility of this system nicely unites a concern for discipline-specific needs with that of federal accessibility standards ${ }^{3}$ and current World Wide Web Consortium guidelines. ${ }^{4}$ Moreover, librarians are able to create new guides and update the content of existing ones independent of the King Library Web Team, without having to maintain proficiency in Web development languages themselves.

More rigorous investigation into how academic subject guides are used by different campus communities in a university setting will provide librarians with a more accurate measure of student learning outcomes. Use of subject guides is likely to differ from one school to the next, depending on the size of the student body, the focus of curricula, students' use of the library, and a host of other factors. Since it is impractical to investigate all types of users interacting with all types of subject guides, this research - a case study - examines the use of subject guides at San José State University among students in three different areas of study-Nursing, Journalism \& Mass Communications, and Organization \& Management. ${ }^{5}$ In particular, this exploratory study seeks to answer the following questions:

- How frequently do students in different academic programs at San José State University use subject guides? Are there unique trends in use among different groups?

- What factors, if any, positively impact the use of subject guides among students?

- Do students perceive subject guides as useful?

- How can librarians make subject guides more useful for different academic communities at San José State University?

\section{Literature Review}

While much of the literature on subject guides focuses on establishing guidelines, formats, and cost-cutting measures, very few of these recommendations are backed by user-centered data. Even studies involving usability testing of subject guide Web pages with student and faculty participants are questionable since test samples are too small to be generalizable. However, survey research conducted in this area shows the potential of reaching a broader audience.

\section{Lack of User-Centered Data}

Early recommendations on subject guide creation stress consistency of format and include a number of potential content ideas, yet offer no insight into how users perceive them. Warner outlines how subject guides at MIT adhere to a rigid pattern of introduction and definition of scope along with lists of books, encyclopedias, handbooks, bibliographies, journals, 
journal articles, reviews, symposiums, and government documents whenever appropriate. ${ }^{6}$ Stevens, Canfield, and Gardner add that subject guides contain lists of subject headings. ${ }^{7}$ Breivik notes that subject guides should also include indexes, abstracts, and other relevant supplemental materials. ${ }^{8}$

In subsequent articles, user needs are looked at and mentioned, but not backed by any empirical evidence or user feedback. Jackson emphasizes a need to change headings in subject guides from a type of source to a process or action to be accomplished. ${ }^{9}$ He points to the example of older headings such as Abstracts, Indexes, Monographs, and Bibliographies and suggests replacing them with new headings that reduce library jargon, like Getting Started, Finding Articles in Journals, and Finding Lists of Other Sources. Similarly, Peterson and Coniglio comment on the readability of subject guides from seven large academic libraries. ${ }^{10}$ They conclude that library tools and information are not easy to explain or understand, and that the subject guides selected for the study were found to be written at a complex reading level, one that needed to be simplified in order for students to make proper use of them. However, student users were not involved in their study.

Later studies emphasize the need for usable subject guides beyond improved readability. Kapoun notes that subject guides should not be so patterned and formulaic that they fail to guide students down different avenues of the research process. ${ }^{11}$ Laverty expands on that criticism by suggesting that subject guides include "a complete research strategy within a subject area rather than limitation to the traditional list of reference tools." 12 She further notes that building in active links to instructions on how to use different resources (e.g., the library catalog) helps to make the subject guide a more complete research tool. Also, Dahl points to a number of guidelines for creating subject guides including consistency, readability, and usability. ${ }^{13}$ However, once again, these guidelines are not defined by user studies.

Morville and Wickhorst emphasize guidelines in selecting electronic resources for inclusion in online subject guides to help patrons make sense of the vast amounts of information available on the Internet. ${ }^{14}$ They recommend that librarians consult virtual libraries, Web information directories, Internet search engines, and online communities for different electronic resources and check them against criteria for inclusion in the guide. Silet reiterates the need for criteria governing the selection of Web resources for subject guides. ${ }^{15} \mathrm{He}$ further notes the need to document them as part of the library's overall collection development policies. Certainly, having selection criteria makes sense. However, little insight is provided on how subject guides are actually used by patrons.

Some authors emphasize the need to save time by pooling resources and collaborating with other libraries and campus communities in building subject guides. For example, Stevens, Canfield, and Gardner claim that building a subject guide takes about fifteen hours (although it is unclear how they arrive at this conclusion) and advise librarians to share their guides and adapt others' for their own use to conserve staff resources. ${ }^{16}$ Warner also points to the possibility of interviewing library volunteers for creating subject guides in the interest of saving time. ${ }^{17}$ Thompson and Stevens detail a project in which one of the authors worked with a library science reference class to develop a series of subject guides for different topics. ${ }^{18}$ This, they claim, enabled library science students to practice their research and collection development skills in a particular subject area, while at the same time helping supply the library with new subject guides to assist other students. Similarly, Sugarman and Demetracopoulos discuss their partnership with teaching faculty, graduate students, and other librarians in creating a world history subject guide to broaden the scope 
of accessible resources and build a vested interest in its use. ${ }^{19}$

More recently, a number of commercial products and new technologies have emerged that may be used to assist librarians in further streamlining the creation of subject guides. Antelman describes the benefits of database-driven technologies that allow Web managers to control the information architecture and maintain design consistency of library Web sites. ${ }^{20}$ Bills, Cheng, and Nathanson describe examples of two libraries using relational databases to diminish the time needed to create subject guides. ${ }^{21}$ They note that with a database-driven solution in place, librarians no longer have to maintain proficiency in Web development languages and skills. Further, since identical resources and descriptions often occur in multiple subject guides, duplication and maintenance efforts are largely reduced through this new technology. OCLC's Pathfinder, Educate Consortium's Into Info, and Ex Libris' Metalib are several products that manage subject-specific resources as part of their overall features.

\section{Limitations of Usability Testing}

Even studies that seek to address user concerns have their share of limitations. Several authors have conducted Web site usability studies in an attempt to discover the usefulness of subject guides as research tools with their targeted audience: students and faculty. At the University of Washington, two graduate students, seven undergraduate students, and one teaching faculty member participated in usability testing of subject guides. Most of the participants noted that they rarely or never used the subject guides for research purposes. ${ }^{22}$ At the Massachusetts Institute of Technology, usability testing of the MIT Library's Web site, catalog, subject guides, and databases was conducted with twelve graduate and nine undergraduate students. Overall findings showed that students were not familiar with these pages. ${ }^{23}$ At the University of Rochester, Reeb and Gibbons conclude that students "do not relate well to subject guides" on the basis of several usability tests with a small number of participants as well as other findings in the literature. ${ }^{24}$

While the above studies seek to include a mix of academic users from various majors and research fields, the samples are too small to be representative of the heterogeneous user population of a university. Nielsen and Landauer's mathematical formula supporting the use of a small group of test participants is meant to be applied to a homogeneous test group, not a university full of students and faculty specializing in different disciplines with diverse research skills and needs. ${ }^{25}$

\section{Survey Research Shows Promise}

Survey studies that investigate the use of subject guides offer more promising results because they have the potential to reach a wider audience and yield more generalizable data. At Duke University, over one thousand library patrons were questioned on their use of subject guides by way of a Web site pop-up and e-mail survey. The results revealed that $53 \%$ had never used subject guides, and another $24 \%$ reported rare usage. ${ }^{26}$ In another study, undergraduate students filled out a survey after participating in usability testing of the Bucknell University Library's subject pages. ${ }^{27}$ The survey instrument itself is one of the more thorough in that it asks students to rate the usefulness of fifteen different sections of the library's subject guide pages. But the survey is administered to only twenty-one users.

Ultimately, research into subject guide use is still at an exploratory stage. There is little, if any, statistically significant data indicating usage trends of different university communities. A more creative approach to survey research is needed to cover representative samples of different user groups and yield generalizable findings. Once this has been established, more focused qualitative approaches such as usability testing and focus group studies can be employed to observe user behaviors in greater depth, further enhancing 
our understanding of how campus communities interact with subject guides.

\section{Methodology}

Three different student survey instruments were developed for the following disciplines and subject guides: Nursing, Journalism \& Mass Communications, and Organization \& Management (see a list of San José State University subject guide pages at http://www.sjlibrary.org/research/ databases/index.htm?getType=5). Each questionnaire was developed to gather as much usage information as possible within a short period of time, roughly 5 to 10 minutes. (See Appendix 1 for a survey template.) Nearly all questions contained standard answers for participants to choose from as well as an opportunity to provide further comments for clarification or to describe a scenario not covered in the identified possibilities. Appropriate questionnaires were then distributed to undergraduate students in the three disciplines to see if students used the various pages of the subject guide in their area of study and, if so, how useful they found the pages.

\section{Survey Instrument Design}

The survey questionnaires contained questions on both individual background and behavioral issues. In particular, students were asked about their major, gender, where they started undergraduate work, and whether or not they had received library instruction at San José State University. Questions on behavioral issues focused on how often students had used each page in an associated subject guide in the past year: never, 1-5 times, 6-10 times, and more than 10 times. If they had used a particular page, they were further asked to rate its usefulness on a five-point Likert scale: very useful, somewhat useful, undecided, not so useful, and not useful at all.

Students were also asked to identify different resources they used for research purposes, including a professor's course page, e-journal lists, reference books from the library, circulating books from the library, theses or dissertations, printed newspaper sources, online newspaper sources, printed periodicals for popular magazine articles, printed periodicals for scholarly articles, course reserves, interlibrary loan, Link+ (a local union catalog), and specific Web resources. In particular, this data helped to determine how students came across the subject guide, either directly or through another section on the Web site, and whether or not the resources they regularly use are made available through subject guides.

A screen grab (snapshot of screen display) of each subject guide page was presented in the questionnaires in case students did not know what a subject guide was or were unsure to which page they were actually being referred. The screen grabs were large enough that students could see key content features on each subject guide page.

The survey questionnaire was formatted so that each page contained a single screen grab of a subject guide page with related questions. This enabled students to focus easily on answering questions about each subject guide page without having to flip back through pages of the questionnaire to find a particular screen grab related to a question on another page. As an additional tactic of effort reduction, the same set of questions were asked in reference to each screen grab, minimizing the amount of new information and mind-shifting required to read, comprehend, and answer the survey questions.

\section{Pilot Study}

Each survey questionnaire was pilot tested prior to distribution to determine if the wording of questions was clear, how long it took to complete the survey, and whether there were any points of confusion to take into consideration. Student volunteers from the School of Nursing, the Department of Organization \& Management, and the School of Journalism \& Mass Communications were recruited 
by librarians in these subject areas to participate in the pilot test. At least five students from each discipline participated in the pilot testing. Each student made an individual appointment to complete the survey questionnaire under the author's supervision. Students were timed on how long they took to complete the survey. Timing was of particular concern because the student survey questionnaires ranged from 7 to 9 pages, and teaching faculty would be reluctant to include the survey in their class session if it took too much time to complete. Fortunately, students took only 5 to 10 minutes to complete the survey. It seems that effort-reduction tactics employed during the survey design were successful.

After students completed the survey questionnaire, they were asked to indicate whether the questions made sense to them and if there were any that were confusing. Responses helped to reshape questions and wording to improve clarity.

\section{Sampling of Research Populations}

A random sample of courses was generated in each discipline. This ensured both small and large, introductory and specialized courses would have an equal chance to be included in the study. However, survey responses covered student subject guide use over the past year, including both current and past semester courses. Consequently, this study examines how students in a variety of field-related courses make use of subject guides within particular disciplines. Further investigation into how students use subject guides at the course level is set aside for future studies.

To get a random selection of courses in each discipline, three separate lists of courses offered during the spring 2005 semester were generated from the SJSU registration database: one for the School of Nursing, another for the School of Journalism \& Mass Communications, and a third for the
Department of Organization \& Management. Ascending accession numbers were then assigned to courses on each list. Finally, each list was randomized using a cryptographic algorithm to generate true random numbers. ${ }^{28}$

Going down each list one by one, classes with randomly selected accession numbers were identified and surveys distributed until a proportionate sample size was reached in each discipline. The number of courses surveyed in each discipline was determined based on the size of the student research population, the size of each class, and overall student attendance rates in a given class at the time the survey was distributed. Ultimately, 10 classes in Nursing, 14 in Journalism \& Mass Communications, and 19 in Organization \& Management were surveyed. In all, 255 out of 1,216 declared Nursing majors (21.0\%), 247 out of 691 declared Journalism \& Mass Communications majors (35.7\%), and 529 out of 1,539 declared Organization \& Management majors $(34.3 \%)$ were surveyed during the spring 2005 semester. ${ }^{29}$ (See table 1 for more details.)

\section{Administration of Surveys}

With the help of librarian subject specialists in Nursing, Journalism \& Mass Communications, and Organization \& Management, the faculty chair was identified in each discipline at the beginning of the spring 2005 semester. A meeting was set up with each chair to discuss the goals of the research project and its potential benefits to students and faculty. The chair

\begin{tabular}{|l|r|r|c|}
\hline \multicolumn{4}{|c|}{ TABLE 1 } \\
\hline Class Level Percentages by Discipline \\
\hline \hline Class Level & Nursing & $\begin{array}{c}\text { Journalism } \\
\text { MC }\end{array}$ & $\begin{array}{c}\text { Organization } \\
\text { Mgmt. }\end{array}$ \\
\hline Freshman & $0.4 \%$ & $2.8 \%$ & $8.7 \%$ \\
\hline Sophomore & $2.4 \%$ & $8.9 \%$ & $1.7 \%$ \\
\hline Junior & $41.2 \%$ & $47.2 \%$ & $41.1 \%$ \\
\hline Senior & $48.6 \%$ & $34.1 \%$ & $46.6 \%$ \\
\hline Other & $7.4 \%$ & $7.0 \%$ & $1.9 \%$ \\
\hline
\end{tabular}


was then asked to encourage other faculty members to participate if their particular course(s) were randomly chosen.

Instructors of selected courses were then contacted via e-mail and asked to allocate 5 to 10 minutes at the beginning or end of one class session so that survey questionnaires could be distributed to and then collected from students in attendance. Students were specifically asked in each course setting whether or not they had already taken the survey in another class. Only those who had not taken the survey were included in the current datagathering process.

\section{Data Analysis}

All student survey responses were collected during regularly scheduled class meetings. In some cases, when students arrived late to class and were unable to finish the survey within the allotted time, the author discarded such responses. Once all survey responses were collected from students, they were coded and entered into the SPSS program. Descriptive statistics were generated and chi-square tests for statistical significance were conducted to reveal potential correlations.

\section{Student Demographics}

The author surveyed 1,031 students across three disciplines in this study. Nearly all student responses are from undergraduate juniors and seniors taking Nursing, Journalism \& Mass Communications, and Organization \& Management courses. However, a few graduates, second baccalaureates, and unclassified students (4.5\% overall) taking undergraduate courses in these disciplines were included in the survey.

The Nursing, Journalism \& Mass Communications, and Organization \& Management survey questionnaires each included an open-ended question asking students to indicate their major area of study. While all Nursing students reported their major as "Nursing," both Journalism \& Mass Communications and Organization \& Management students reported a range of specializations and majors not formally recognized by their respective departments. ${ }^{30}$ (See table 2 for more details.)

\section{Articles \& Databases Page Gets High Use}

Nursing, Journalism \& Mass Communications, and Organization \& Management students were asked to rate how frequently they used individual pages of their subject guides on the SJLibrary. org Web site in the past year using the following scale: never, 1-5 times, 6-10 times, and more than 10 times. If students indicated using the pages before, they were further asked to rate the usefulness of the pages on a five-point Likert scale.

By far, the list of online databases is the most heavily used page of all subject guides, although Nursing students reported more use of this page than students in the other two disciplines. Most Organization \& Management students $(66.5 \%)$ reported using the Articles \& Databases page of their subject guide, with $30.1 \%$ reporting use of more than 5 times in the past year. Journalism students have a higher use rate at $76.1 \%$, and $41.7 \%$ indicated using the Articles \& Databases page more than 5 times. Additionally, nearly all Nursing students (91.7\%) indicated using the page, and almost half (46.2\%) reported using the page more than 5 times in the past year.

High use of the Articles \& Databases pages is further confirmed by students' level of familiarity with accessing databases through their subject guides and as standalone online resources. On the SJLibrary.org Web site, students can link directly to an Articles \& Database page from the homepage. Once on the Articles $\&$ Databases homepage, they can search for databases by general subject area, by SJSU subjects or majors, or by an alphabetical listing. If students choose to search for databases by SJSU subjects or majors, they enter the subject guides. Otherwise, they bypass the subject guides to use the tool in a different fashion. 


\begin{tabular}{|c|c|c|}
\hline \multicolumn{3}{|c|}{$\begin{array}{c}\text { TABLE } 2 \\
\text { Reported Majors from Students by Discipline }\end{array}$} \\
\hline Discipline & Reported Major & $\begin{array}{c}\text { Total } \\
\text { Students }\end{array}$ \\
\hline Nursing & Nursing & $100.0 \%$ \\
\hline \multirow{11}{*}{$\begin{array}{l}\text { Journalism } \\
\& M C\end{array}$} & Advertising & $33.9 \%$ \\
\hline & Public Relations & $24.1 \%$ \\
\hline & Journalism & $13.9 \%$ \\
\hline & Photojournalism & $6.1 \%$ \\
\hline & $\begin{array}{l}\text { Broadcasting or Radio, } \\
\text { Television \& Film }\end{array}$ & $4.9 \%$ \\
\hline & Marketing \& Design Studies & $3.3 \%$ \\
\hline & $\begin{array}{l}\text { Magazine \& Print } \\
\text { Journalism }\end{array}$ & $3.2 \%$ \\
\hline & Mass Communications & $2.4 \%$ \\
\hline & Communication Studies & $2.0 \%$ \\
\hline & Reporting \& Editing & $1.7 \%$ \\
\hline & $\begin{array}{l}\text { Undeclared or Unrelated } \\
\text { Field }\end{array}$ & $4.5 \%$ \\
\hline \multirow{16}{*}{$\begin{array}{l}\text { Organization } \\
\& \text { Mgmt. }\end{array}$} & $\begin{array}{l}\text { Organization \& } \\
\text { Management }\end{array}$ & $42.4 \%$ \\
\hline & Marketing & $7.4 \%$ \\
\hline & Accounting & $6.6 \%$ \\
\hline & Business Administration & $6.4 \%$ \\
\hline & International Business & $5.5 \%$ \\
\hline & Finance & $5.1 \%$ \\
\hline & Business & $4.5 \%$ \\
\hline & Hospitality Management & $3.6 \%$ \\
\hline & $\begin{array}{l}\text { Management Information } \\
\text { Systems }\end{array}$ & $3.2 \%$ \\
\hline & $\begin{array}{l}\text { Human Resource } \\
\text { Management }\end{array}$ & $2.3 \%$ \\
\hline & Aviation Management & $1.7 \%$ \\
\hline & $\begin{array}{l}\text { Corporate Finance } \\
\text { Management }\end{array}$ & $1.3 \%$ \\
\hline & Communication Studies & $1.3 \%$ \\
\hline & $\begin{array}{l}\text { Accounting Information } \\
\text { Systems }\end{array}$ & $0.9 \%$ \\
\hline & $\begin{array}{l}\text { Engineering Operation } \\
\text { Management }\end{array}$ & $0.7 \%$ \\
\hline & $\begin{array}{l}\text { Undeclared or Unrelated } \\
\text { Field }\end{array}$ & $7.1 \%$ \\
\hline
\end{tabular}

\section{Recognition of Subject Guide Homepage}

Nursing students appear to recognize the homepage of their subject guide as a starting point for research more frequently than students in the other two disciplines. A total of $70.2 \%$ of Nursing students reported using the subject guide homepage in comparison to $61.5 \%$ of Journalism \& Mass Communications students and $39.5 \%$ of Organization \& Management students.

\section{Less Frequently Used Subject Guide Pages}

Aside from the Articles \& Databases page, students across the three disciplines appear to be using other pages within their guide less frequently.

Even the Web Sites page of the Organization \& Management subject guide, which caters specifically to the BUS3 146 (Project Management) and BUS3 160 (Fundamentals of Management and Organizational Behavior) students, is used less frequently. When a subset of students in this study $(n=126)$ was surveyed in two BUS3 160 classes and one BUS3 146 class about their use of the Web Sites page, $77.7 \%$ reported never using this page, $13.5 \%$ reported using the page 1-5 times in the past year, and only $8.8 \%$ reported using the page more than 5 times in the past year. Organization \& Management students reported less overall use of the Campus Links page (28.2\%), Scholarly vs. Popular Articles page $(26.7 \%)$, Citing \& Writing page $(18.3 \%)$, Web Sites page $(17.6 \%)$, Search Tips page $(10.7 \%)$, and Evaluating Information page (7.7\%). 
Journalism \& Mass Communications students share similar usage trends with Organization \& Management students with few exceptions. They reported less use of information literacy pages such as Plagiarism (15.4\%), Citing \& Writing (15.4\%), Search Tips (13.4\%), and Evaluating Information (9.3\%). However, Journalism students reported more frequent use of the Scholarly vs. Popular Articles page $(43.3 \%)$ and the Web Sites page $(31.2 \%)$, though most of them reported using these pages fewer than five times in the past year.

Similarly, Nursing students reported less use of other pages in their subject guide. While $54.8 \%$ of Nursing students reported using the Books page, only $16.2 \%$ reported frequent use, with most of them reporting use of 1-5 times in the past year $(38.6 \%)$. Similarly, $39.0 \%$ indicated using the Related Subjects \& Guides page but only $6.3 \%$ indicated more frequent use. This same trend applies to the Federal Government Sources page, which only
$27.9 \%$ noted using and $9.8 \%$ noted using more frequently. The Legislation page has the least amount of use $(10.2 \%)$, with only $2.0 \%$ reporting use of more than 5 times a year.

\section{Use of Other Library Resources}

In addition to being asked about how frequently they used different pages of their subject guide, students were also asked to identify other library tools they use outside of the subject guides, including e-journals, the library catalog, print sources, and online databases. Nursing students reported higher levels of use of the databases through both the subject guides $(91.7 \%)$ and elsewhere (83.9\%) on the site. Journalism \& Mass Communications reported less frequent use at $76.1 \%$ and $76.9 \%$ respectively, and Organization \& Management students reported the lowest use at $66.5 \%$ and $75.2 \%$ respectively.

When asked to identify research tools they use regularly, students from

\begin{tabular}{|l|c|c|c|}
\hline \multicolumn{4}{|c|}{ TABLE 3 } \\
Use of Different Research Tools by Discipline \\
\hline \hline Research Tool & $\begin{array}{c}\text { Nursing } \\
\text { Student Use }\end{array}$ & $\begin{array}{c}\text { Journalism \& } \\
\text { MC Student } \\
\text { Use }\end{array}$ & $\begin{array}{c}\text { Organization \& } \\
\text { Mgmt. Student } \\
\text { Use }\end{array}$ \\
\hline Professor's Course Page & $20.8 \%$ & $40.9 \%$ & $42.7 \%$ \\
\hline E-journals Lists & $42.7 \%$ & $19.8 \%$ & $21.2 \%$ \\
\hline Online Articles \& Databases & $83.9 \%$ & $76.9 \%$ & $75.2 \%$ \\
\hline Theses or Dissertations & $5.1 \%$ & $4.5 \%$ & $3.2 \%$ \\
\hline Printed Newspaper Sources & $9.0 \%$ & $54.7 \%$ & $37.4 \%$ \\
\hline Online Newspaper Sources & $25.1 \%$ & $71.7 \%$ & $60.5 \%$ \\
\hline Bound Popular Magazine Sources & $16.5 \%$ & $36.0 \%$ & $23.1 \%$ \\
\hline Bound Scholarly Article Sources & $31.0 \%$ & $33.6 \%$ & $18.3 \%$ \\
\hline Circulating Library Books & $32.2 \%$ & $32.8 \%$ & $28.9 \%$ \\
\hline Library Reference Books & $32.5 \%$ & $39.3 \%$ & $33.1 \%$ \\
\hline Course Reserves & $11.0 \%$ & $11.3 \%$ & $10.6 \%$ \\
\hline Interlibrary Loan & $7.1 \%$ & $3.2 \%$ & $5.1 \%$ \\
\hline Link+ & $9.4 \%$ & $8.9 \%$ & $10.6 \%$ \\
\hline Online Catalog & $37.6 \%$ & $32.0 \%$ & $27.6 \%$ \\
\hline Web Site Search Engines & $43.1 \%$ & $68.8 \%$ & $63.5 \%$ \\
\hline
\end{tabular}


all three disciplines reported higher use of online databases than any other resource. However, students within the three disciplines illustrated unique usage trends as well. Journalism \& Mass Communications students reported more use of news resources related to their field. More than half $(54.7 \%)$ reported use of printed materials and $71.7 \%$ reported use of online newspaper sources, which is in contrast to Organization \& Management (37.4\% and $60.5 \%$ respectively) and Nursing $(9.0 \%$ and $25.1 \%$ respectively) students. Organization \& Management $(42.7 \%)$ and Journalism \& Mass Communications $(40.9 \%)$ students reported higher use of instructors' Web sites than Nursing students (20.8\%). Additionally, Organization \& Management (18.3\%) students reported lower use of bound scholarly article sources than Journalism \& Mass Communications (33.6\%) and Nursing (31.0\%) students. (See table 3 for specific comparisons.)

\section{Students' Perceptions of Usefulness}

Students generally find the Articles \& Databases page of their subject guide to be "very useful" or "somewhat useful," with most favorable rankings coming from Nursing students. Just over a third $(36.9 \%)$ of Organization \& Management students rated the page "very useful," $48.4 \%$ of Journalism \& Mass Communications students found the page "very useful," and over half of the Nursing students $(52.5 \%)$ found the page "very useful." Similarly, $4.7 \%$ of Organization \& Man-

\begin{tabular}{|c|c|c|c|c|c|c|}
\hline \multicolumn{7}{|c|}{$\begin{array}{c}\text { TABLE } 4 \\
\text { Subject Guide Pages \& Students' Perceptions of Usefulness }\end{array}$} \\
\hline \multicolumn{2}{|c|}{ Subject Guide Page } & 1 & 2 & 3 & 4 & 5 \\
\hline \multirow{5}{*}{ Nursing } & Articles \& Databases & $52.5 \%$ & $42.2 \%$ & $4.0 \%$ & $0.9 \%$ & $0.4 \%$ \\
\hline & Books & $34.8 \%$ & $53.8 \%$ & $7.6 \%$ & $3.0 \%$ & $0.8 \%$ \\
\hline & Fed. Govt. Sources & $42.3 \%$ & $47.9 \%$ & $7.0 \%$ & $2.8 \%$ & $0.0 \%$ \\
\hline & Legislation & $46.2 \%$ & $50.0 \%$ & $3.8 \%$ & $0.0 \%$ & $0.0 \%$ \\
\hline & Related Guides & $29.9 \%$ & $59.8 \%$ & $9.3 \%$ & $1.0 \%$ & $0.0 \%$ \\
\hline \multirow{7}{*}{$\begin{array}{l}\text { Journalism } \\
\& M C\end{array}$} & Articles \& Databases & $48.4 \%$ & $42.3 \%$ & $6.1 \%$ & $2.7 \%$ & $0.5 \%$ \\
\hline & Web Sites & $26.7 \%$ & $49.3 \%$ & $20.0 \%$ & $1.3 \%$ & $2.7 \%$ \\
\hline & Plagiarism & $27.0 \%$ & $56.8 \%$ & $10.8 \%$ & $2.7 \%$ & $2.7 \%$ \\
\hline & Citing \& Writing & $27.1 \%$ & $48.6 \%$ & $18.9 \%$ & $2.7 \%$ & $2.7 \%$ \\
\hline & Evaluating Info. & $26.2 \%$ & $56.5 \%$ & $8.7 \%$ & $4.3 \%$ & $4.3 \%$ \\
\hline & Scholarly vs. Popular & $31.4 \%$ & $53.3 \%$ & $12.4 \%$ & $2.9 \%$ & $0.0 \%$ \\
\hline & Search Tips & $37.5 \%$ & $53.1 \%$ & $9.4 \%$ & $0.0 \%$ & $0.0 \%$ \\
\hline \multirow{7}{*}{$\begin{array}{l}\text { Organization } \\
\& \text { Mgmt. }\end{array}$} & Articles \& Databases & $36.9 \%$ & $52.0 \%$ & $6.4 \%$ & $3.5 \%$ & $1.2 \%$ \\
\hline & Campus Links & $23.4 \%$ & $61.7 \%$ & $10.6 \%$ & $4.3 \%$ & $0.0 \%$ \\
\hline & Web Sites & $23.4 \%$ & $61.7 \%$ & $10.6 \%$ & $4.3 \%$ & $0.0 \%$ \\
\hline & Citing \& Writing & $42.7 \%$ & $45.8 \%$ & $7.3 \%$ & $2.1 \%$ & $2.1 \%$ \\
\hline & Evaluating Info. & $36.6 \%$ & $41.5 \%$ & $19.5 \%$ & $0.0 \%$ & $2.4 \%$ \\
\hline & Scholarly vs. Popular & $29.9 \%$ & $54.0 \%$ & $14.6 \%$ & $1.5 \%$ & $0.0 \%$ \\
\hline & Search Tips & $35.1 \%$ & $47.4 \%$ & $7.0 \%$ & $7.0 \%$ & $3.5 \%$ \\
\hline
\end{tabular}


agement students (in comparison to $3.2 \%$ of Journalism \& Mass Communications students and $1.3 \%$ of Nursing students) describe the Articles \& Databases page "not so useful" or "not useful at all."

Aside from the Articles \& Databases page, most pages within the different subject guides were also rated "very useful" or "somewhat useful," despite less overall use. In general, Journalism \& Mass Communications and Organization \& Management students are more likely to rate pages as "undecided," "not so useful," or "not useful at all." In particular, Journalism \& Mass Communication students found the Citing \& Writing page and the Evaluating Information page more difficult to use than Organization \& Management students. But Journalism \& Mass Communications students fared better with the Search Tips page than did Organization \& Management students. (See table 4 for more details on how students ranked the usefulness of different pages.)

\section{Library Instruction and Subject Guide Use}

Students who received library instruction at San José State University tended to use subject guide pages more frequently. A statistically significant correlation was found between attendance at library instruction sessions and the reported frequency of using the Articles \& Databases page $\left(\chi^{2}=179.631, p<.0005\right)$ among students across the three disciplines $(n=965)$. Of those who received library instruction, $44.5 \%$ reported using the Articles \& Database page more than 5 times a year in comparison to those who did not receive library instruction (15.9\%).

Students who received library instruction also made more use of the subject guide homepage than those who did not $\left(\chi^{2}=99.466, p<.0005\right)$. Of those who had library instruction, $21.1 \%$ reported they had used the subject guide homepage more than 5 times a year compared to $7.3 \%$ of those who had no library instruction. Moreover, $73.7 \%$ of students who did not have library instruction reported having never used the subject guide homepage, while only $37.4 \%$ of students who received library instruction reported the same behavior.

These trends are further reflected in the data collected within each discipline. Most nursing students $(82.4 \%)$ received library instruction and reported the highest use of the Articles \& Databases page (91.7\%) as well as their subject guide homepage (70.2\%). Journalism \& Mass Communications students reported a lower percentage of library instruction $(72.1 \%)$ and a corresponding lower rate of use for the Articles \& Databases page $(76.1 \%)$ and the subject guide homepage (61.5\%). Finally, Organization \& Management students reported the lowest incidence of library instruction $(62.6 \%)$, also the lowest use of the Articles \& Databases page $(66.5 \%)$ and subject guide homepage (39.5\%).

Additionally, library instruction attendance seems to be correlated with students' academic levels. It was found that seniors used subject guide pages more frequently than juniors $\left(\chi^{2}=25.436\right.$, $p<.0005)$. Seniors $(56.0 \%)$ were more likely to have had library instruction than juniors (44.0\%). Similarly, $64.3 \%$ of juniors reported not having library instruction, while only $35.7 \%$ of seniors indicated so.

Seniors were also found more likely to make frequent use of the Articles $\&$ Databases page than juniors $\left(\chi^{2}=\right.$ $16.649, p<.0005)$. Fewer $(15.2 \%)$ seniors reported having never used the Articles \& Databases page of their subject guide compared to juniors $(31.3 \%)$. On the other hand, $47.9 \%$ of seniors indicated having used the Articles \& Databases page more than 5 times a year, whereas only $27.6 \%$ of juniors indicated use at such frequency.

Unsurprisingly, seniors were also more likely to have used the subject guide homepage as a starting point for their research than juniors $\left(\chi^{2}=49.962, p\right.$ $<.0005)$. Only $12.6 \%$ of juniors reported having used their subject guide homepage, while $22.9 \%$ of seniors indicated use of their subject guide homepage. 


\section{Conclusion: Discussion and Future Research}

Through the deployment of three survey instruments, this case study focuses on the actual use and perceived usefulness of subject guides among undergraduate students in Nursing, Journalism \& Mass Communications, and Organization \& Management at San José State University during the spring 2005 semester. Overall findings of this study indicate that students who have received library instruction are likely to make more frequent use of subject guides, although students are mainly using the Articles \& Databases page within their subject guide. Moreover, library instruction attendance appears to be correlated with student academic levels. In general, seniors are more likely to have attended a library instruction session than juniors, and seniors report more frequent use of subject guides. Moreover, students generally described the subject guides as "very useful" or "somewhat useful" no matter how frequently they used them.

In addition to questions on general use and perceived usefulness of subject guides, students were also asked to indicate any other resources they used to complete course assignments, which allowed the author to further determine the comprehensiveness of existing subject guides.

\section{Enriching Current Subject Guides}

Based on student survey responses, the Nursing, Journalism \& Mass Communications, and Organization \& Management subject guides at San José State University can be improved upon in several ways. In general, librarians can link to department pages that contain teaching faculty's course Web pages, particularly on the Journalism \& Mass Communications and Organization \& Management subject guides, since these students reported higher use of those pages. Including links to appropriate Web sites students use frequently might also be helpful.

Librarians can also provide access to more library tools that students use regu- larly or those they would like students to use more often. Serials Solutions has enabled students to obtain a list of all journal titles available electronically at King Library in their particular area of study. Nursing students reported using the e-journals list twice as much as those in Journalism \& Mass Communications and Organization \& Management. Adding a direct link to this subject-specific information could create a more comprehensive research guide for students who regularly use the tool and raise more awareness of its availability to others.

Journalism \& Mass Communications students reported high use of print and online newspaper resources. Creating a separate page of news sources in this subject guide might prove useful. Also, since these students described their major area of study in different ways, the librarian in this subject area may want to explore categorizing resources under these headings or even creating a separate subject guide for some of them. For example, over one third $(33.9 \%)$ of Journalism \& Mass Communications students described their major as Advertising, suggesting that a new subject guide in this area could be useful.

These same general recommendations can be applied to the Organization \& Management subject guide, since students taking these courses also described their majors in multiple ways. A few students identified their major as "Human Resource Management," "Aviation Management," "Corporate Finance Management," "Accounting \& Information Systems," and "Engineering \& Operation Management." These subject areas could be subtitles for categorizing resources within the Organization \& Management subject guide. Additionally, a page of related subjects could be added with links to existing subject areas that students identified: Marketing \& Decision Sciences, Accounting \& Finance, Hospitality Management, Management Information Systems, International Business, Business, and Communication Studies. 
Once all changes are in place, more user-centered studies can be conducted to see how well they support students' needs or if new problems must be addressed.

\section{Implications}

College and university libraries contain a maze of different research routes, whether a History student is trying to filter items in the library catalog for primary print sources or a Business student is trying to figure out which database and search strategy is most appropriate for finding articles on company structures. By their nature, academic libraries are information rich, and so are their Web sites. Librarians are challenged with presenting the many tools available to students including index resources, reference and background sources, a wide array of online databases, the library catalog, e-journals lists-each with its own unique interface to learnwithout overwhelming them.

Given this predicament, it is not surprising that academic librarians have widely adopted the subject guide as a means of pulling together relevant resources into a single portal for student research on particular topics. Findings from this study, however, indicate that the mere existence of these guides does not ensure students will use them or be confident users. At San José State University, students across three disciplines who received library instruction tended to use subject guide pages more frequently than those who did not receive instruction. Aside from providing students with guidance in the use of different library tools, library instruction sessions emphasize critical thinking to uncover the most relevant materials and incorporate them into a comprehensible form. Students must have the skills to extract and synthesize information from the various resources provided in subject guides for them to be useful.

Despite the communication challenges inherent in differing perceptions of instructional and professional status, librarians at San José State University need to become more proactive in extolling the virtues of library instruction to the teaching faculty. Empirical evidence and statistically significant data are needed to persuade them of the importance and complementary role of library instruction in students' effective use of the library's research tools. This is particularly true for those faculty members whose students do not participate in course-integrated library instruction. Also, increasing university administrators' awareness of the benefits of library instruction may strengthen university policies on library and teaching faculty collaboration, further optimizing student learning outcomes.

Specifically, coordination between library and teaching faculty at San José State University should focus on fine-tuning individual course assignments that are appropriate to information competency initiatives and the resources available at King Library. This should not only involve the development of appropriate course assignments, but corresponding requirements on the types of tools and sources that are acceptable for research in a particular field.

The Information Literacy Assignments Resource Center (http://www. sjlibrary.org/services/literacy/info_comp/ resource_center.htm) on the SJLibrary.org Web site partly addresses the need for more collaboration between library and teaching faculty in this area. The guide is composed of three parts: a summarization of the Association of College \& Research Libraries (ACRL) Information Literacy Competency Standards for Higher Education, common assignments matched to ACRL standards, and actual course assignments from different colleges at San José State University that are matched to ACRL standards. The Literacy Assignments Resource Center is an online resource meant to assist teaching faculty in integrating information literacy principles into their course assignments.

Once student assignments and source requirements have been established that incorporate relevant information literacy 
principles, librarians can work with teaching faculty to determine how best to support individual course assignments with instructional resources such as subject guides.

\section{Future Research}

While this study explores students' use of subject guides during the past year and the author broadly concludes that students make less use of subject guide pages overall (aside from the Articles \& Databases page), a closer examination of how they are using individual pages at the departmental and course level would provide more context in which to assess the data. For example, if students in one Nursing class make use of a particular subject guide page, and this page is otherwise not used by other Nursing students, can the author conclude that overall use is low if the page is specifically created for and valued by this small group? How do students in different types of courses (researchbased, practicum, skills-based) make use of subject guides, and are there specific trends that can better inform the creation of these finding aids? Also, how do other factors such as academic performance and departmental-specific standards impact the use of subject guides in particular courses? How effective are subject guides in assisting students to complete assignments and research projects? For example, what steps are of particular concern to a student getting started with a course research project, and are these steps discernible when the student is using the subject guide?

Subject guides are usually lists of resources, and, according to Carol Kuhlthau, this presentation by itself does not match the Information Search Process (ISP) students go through to find materials. Kuhlthau describes this problem as "a gap between the system's traditional patterns of information provision and the user's natural process of information use." ${ }^{31}$ Based on findings from five studies, Kuhlthau concludes that students engage in common tasks forming six stages of the ISP: initiation, selection, exploration, formulation, collection, and presentation. ${ }^{32}$

Kuhlthau's research is seminal in the field of library and information science, and her work provides important insights that can shape the framework in which library resources are presented to students. A subject guide that incorporates the cognitive process to completing course assignments - steps addressing the different stages of the student ISP-would more closely parallel students' mental model. A better understanding of how these finding aids help or hinder students' completion of course assignments within different academic programs will further inform librarians and teaching faculty of gaps in discipline-specific library instruction, course assignment development, and communication of acceptable research standards.

\section{Notes}

1. Charles Stevens, Marie Canfield, and Jeffrey Gardner, "Library Pathfinders: A New Possibility for Cooperative Reference Service," College and Research Libraries 34 (Jan. 1973): 41.

2. Cohen and Still (Laura Cohen and Julie Still, "A Comparison of Research University and Two-year College Library Web Sites: Content, Functionality and Form," College E Research Libraries 60 (May 1999): 275-89) examined the library homepages of 50 Ph.D.-granting institutions and 50 two-year colleges, finding that $84 \%$ of the research universities and $60 \%$ of the two-year schools referenced subject guides. Grimes and Morris (Marybeth Grimes and Sara Morris, "A Comparison of Academic Libraries' Webliographies," Internet Reference Services Quarterly 5 (2001): 69-77) surveyed librarians at 19 colleges and universities and 18 Association of Southeastern Research Libraries (ASERL) finding that $89 \%$ of respondents from colleges and universities and all respondents from ASERL libraries reported including subject guides as part of their Web site content. Jackson and Pellack (Rebecca Jackson and Lorraine Pellack, "Internet Subject Guides in Academic Libraries: An Analysis of Contents, Practices, and Opinions," Reference and User Services Quarterly 
43 (Summer 2004): 319-27) surveyed 112 members of the Association of Research Libraries (ARL), of which $57 \%$ responded. $75 \%$ of the respondents indicated creating subject guides and nearly half $(49 \%)$ noted that librarians' performance evaluations are influenced by the quality of their subject guides.

3. Section 508 of the Rehabilitation Act Amendments of 1998 requires that electronic information be accessible to persons with disabilities. Available online at http://www.section508.gov [Accessed 7 December 2006].

4. The World Wide Web Consortium (W3C) provides protocols and guidelines to ensure Web site interoperability. Available online at http://www.w3.org. [Accessed 7 December 2006].

5. Originally, this study was planned to include students from the following academic programs: Art \& Design, Computer Science, Nursing, Journalism \& Mass Communications, and Organization \& Management. The five academic programs were chosen based on consideration of the number of undergraduate students enrolled in the programs, the extent to which different types of programs were represented (Sciences, Social Sciences, Humanities, and Applied Sciences), the availability of corresponding librarian subject specialists in this area, and whether or not these librarians had fully developed and promoted their subject guides. However, faculty in the Art \& Design and Computer Science programs ultimately opted to drop out of this study because of curricular demands. As a result, it was not possible to survey students on subject guide use from a balance of disciplines at San José State University.

6. Alice Warner, "Pathfinders: A Way to Boost Your Information Handouts Beyond Booklists and Bibliographies," American Libraries 14 (Mar. 1983): 150-51.

7. Stevens, Canfield, and Gardner, "Library Pathfinders," 40-46.

8. Patricia S. Breivik, Planning the Library Instruction Program (Chicago: American Library Association, 1982).

9. William Jackson, "The User-friendly Library Guide," College \& Research Libraries News 45 (Oct. 1984): 468-71.

10. Lorna Peterson and Jamie Coniglio, "Readability of Selected Academic Library Guides," RQ 27 (Winter 1987): 233-39.

11. Jim Kapoun, "Re-thinking the Library Pathfinder," College and Undergraduate Libraries 2 (May 1995): 93-105.

12. Corinne Laverty, "Library Instruction on the Web: Inventing Options and Opportunities," Internet Reference Services Quarterly 2 (1997): 55-66.

13. Candice Dahl, "Electronic Pathfinders in Academic Libraries: An Analysis of Their Content and Form," College \& Research Libraries 62 (May 2001): 227-37.

14. Peter Morville and Susan Wickhorst, "Building Subject-specific Guides to Internet Resources," Collection Building 14 (1995): 26-31.

15. Scott Silet, "Anatomy of the Internet Reference Resources Web Page: A UVA Library Experiment," Virginia Libraries 45 (1999): 6-10.

16. Stevens, Canfield, and Gardner, "Library Pathfinders."

17. Warner, "Pathfinders."

18. Glenn Thompson and Barbara Stevens, "Library Science Students Develop Pathfinders," College \& Research Libraries News 46 (May 1985): 224-25.

19. Tammy Sugarman and Constance Demetracopoulos, "Creating a Web Research Guide: Collaboration Between Liaisons, Faculty and Students," Reference Services Review 29 (2001): 150-56.

20. Kristin Antelman, "Getting Out of the HTML Business: The Database-driven Web Site Solution," Information Technology and Libraries 18 (Dec. 1999): 176-81.

21. Linda Bills, Rachel Cheng, and Alan Nathanson, "Subject Web Page Management Without HTML Coding: Two Approaches," Information Technology and Libraries 22 (Mar. 2003): 4-11.

22. University Libraries, University of Washington, "By Subjects Usability Study: User Summaries." Available online at http://www.lib.washington.edu/Usability/by-subj/bysubjectusers. html. [Accessed 14 December 2006].

23. Web Advisory Group, MIT Libraries, "Big Test Usability Test Results: Some General Observations." Available online at http://macfadden.mit.edu:9500/webgroup/usability2002/bigtest/observations.html. [Accessed 7 October 2006].

24. Brenda Reeb and Susan Gibbons, "Students, Librarians, and Subject Guides: Improving a Poor Rate of Return," Portal 4 (2004): 123.

25. Jakob Nielson and Thomas Landauer, "A Mathematical Model of the Finding of Usability Problems," Proceedings of ACM INTERCHI'93 Conference (Apr. 1993): 206-13.

26. "Survey Results-Draft: Combined Results: Pop-Up and E-mail: Summary." Available from Emily C. Jackson Sanborn, Reference and Digital Services Librarian, Duke University Libraries; e-mail: emily.jackson.sanborn@duke.edu.

27. Bucknell Information Services and Resources, "Pathfinder Survey Results: Post-Survey Comments"; contact Isabella O'Neill for copies at ioneill@bucknell.edu. 
28. Mads Haahr has created a true random number generator. Available online at

http://www.random.org/sform.html. [Accessed 7 December 2006]. 1

29. The size of each research population was defined by the number of declared majors in a discipline during the spring 2005 semester regardless of whether or not these students were taking courses directly related to their major. However, the School of Nursing kept separate and specific enrollment statistics apart from those generated by the university. While the university estimates 1,216 declared Nursing majors for the spring 2005 semester, the School of Nursing confirms that only 565 of these students were enrolled in Nursing courses. The remaining students were likely fulfilling general education course requirements and were not an appropriate target for questioning the use of the Nursing subject guide. Consequently, the author was actually able to survey a broader percentage of the Nursing student research population $(45.1 \%)$ than reflected in the university statistics. Extrapolating from this trend, the number of students surveyed in the School of Journalism \& Mass Communications and the Department of Organization \& Management likely represents a larger percentage of the respective student research populations as well.

30. At San José State University, the School of Journalism \& Mass Communications recognizes the following programs within its major area of study: Advertising, Journalism, Mass Communications, and Public Relations. The Organization \& Management department recognizes the following concentrations within its major area of study: International Business, Human Resource Management, Management, and Hospitality Management.

31. Carol Kuhlthau, "Inside the Search Process: Information Seeking from the User's Perspective," Journal of the American Society for Information Science 42 (1991): 361.

32. Carol Kuhlthau, "The Process of Learning from Information." In The Virtual School Library: Gateway to the Information Superhighway (Englewood, CO: Libraries Unlimited, 1996).

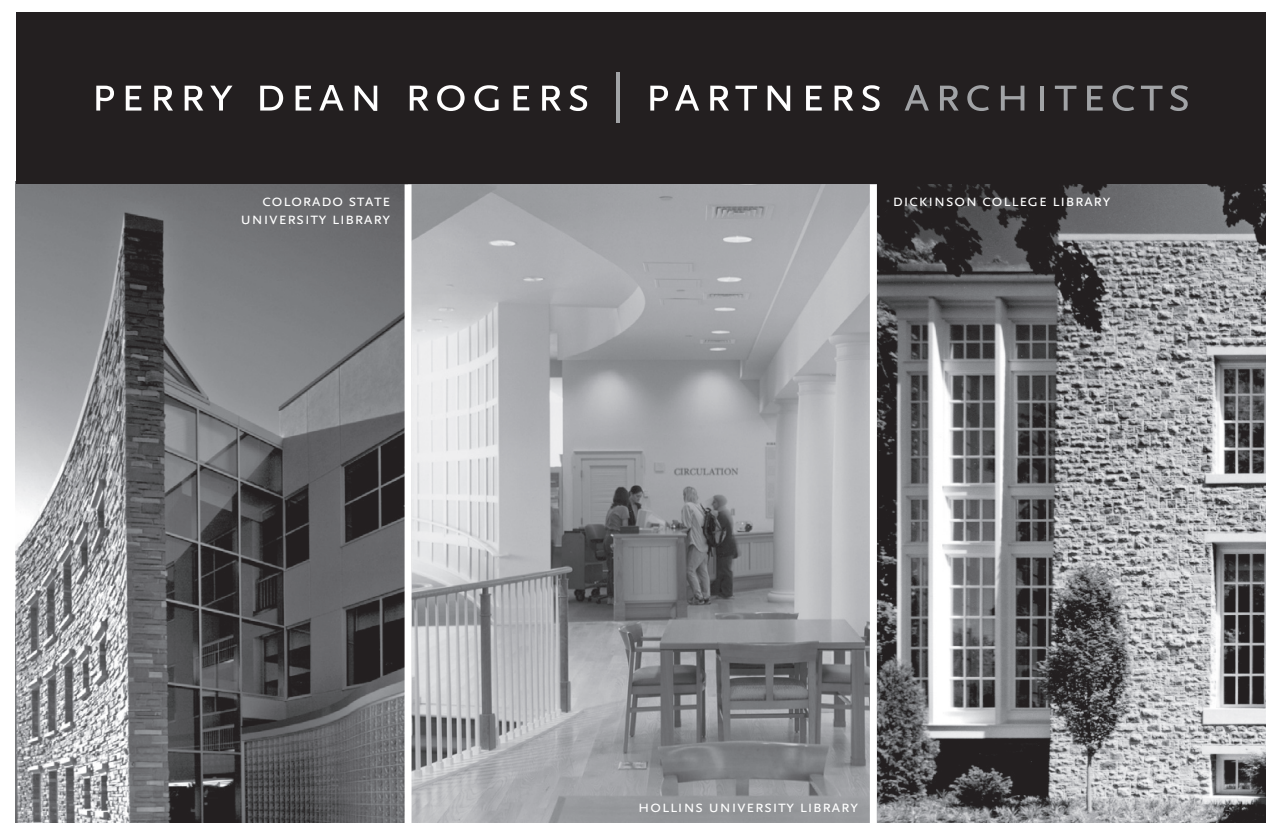

Designers for Libraries \& Academic Institutions 


\section{APPENDIX 1 \\ Student Survey Template}

1. Please indicate your academic level in school:
a. Freshman, Undergraduate
b. Sophomore, Undergraduate
c. Junior, Undergraduate
d. Senior, Undergraduate
e. Graduate
f. Unclassified
g. Other

2. Please indicate your major:

3. Please circle your gender: male female

4. Did you begin college at SJSU or elsewhere? SJSU elsewhere

5. Have you received library instruction before at SJSU Library? no yes not sure

6. Please indicate how often you have used the following subject guide on the King Library Web site within the past year. See the illustration below.

\section{Screen Grab of Subject Guide Homepage}

Note: Image should be large and clear enough for students to read page content

(6. contd.) Please circle the best option that describes how frequently you have used this library Web page within the past year.
a. Never
b. 1-5 times
c. $6-10$ times
d. More than 10 times

Comments (optional): 
7A. How frequently have you used the Articles \& Databases section of the guide in the past year (please see illustration below).

Screen Grab of Subject Guide Articles and Databases Page

Note: Image should be large and clear enough for students to read page content

(7A. contd.) Please circle the best option that describes how frequently you have used this library Web page within the past year.
a. Never
b. 1-5 times
c. 6-10 times
d. More than 10 times

\section{Comments (optional):}

7B. If you chose "Never" as your choice in Question 7A, go to Question 8A.

Otherwise, please indicate how useful you found this page.
a. Very useful
b. Somewhat useful
c. Undecided
d. Not so useful
e. Not useful at all

Comments (optional):

8A. Please specify how frequently you have used this section of the guide in the past year (please see illustration below).

Screen Grab of Subject Guide Page

Note: Image should be large and clear enough for students to read page content 
(8A. contd.) Please circle the best option that describes how frequently you have used this library Web page within the past year.
a. Never
b. 1-5 times
c. 6-10 times
d. More than 10 times

Comments (optional):

8B. If you chose "Never" as your choice in Question 8A, go to Question 9A.

Otherwise, please indicate how useful you found this page.
a. Very useful
b. Somewhat useful
c. Undecided
d. Not so useful
e. Not useful at all

Comments (optional):

9A. Please specify how frequently you have used this section of the guide in the past year (please see illustration below).

\section{Screen Grab of Subject Guide Page}

\section{Note: Image should be large and clear enough for students to read page content}

(9A. contd.) Please circle the best option that describes how frequently you have used this library Web page within the past year.
a. Never
b. 1-5 times
c. 6-10 times
d. More than 10 times

Comments (optional):

9B. If you chose "never" as your choice in Question 9A, go to Question 10A. Otherwise, please indicate how useful you found this page.
a. Very useful
b. Somewhat useful
c. Undecided
d. Not so useful
e. Not useful at all 
Comments (optional):

10A. Please specify how frequently you have used this section of the guide in the past year (please see illustration below).

Screen Grab of Subject Guide Page

Note: Image should be large and clear enough for students to read page content

(10A. contd.) Please circle the best option that describes how frequently you have used this library Web page within the past year.
a. Never
b. 1-5 times
c. 6-10 times
d. More than 10 times

Comments (optional):

10B. If you chose "Never" as your choice in Question 10A, go to Question 11. Otherwise, please indicate how useful you found this page.
a. Very useful
b. Somewhat useful
c. Undecided
d. Not so useful
e. Not useful at all

Comments (optional):

11. What other resources do you use to complete your research or course assignments? Please circle all that apply.
a. Professor's course page
b. E-journals list
c. Online articles \& databases
d. Theses or dissertations
e. Printed newspaper sources
f. Online newspaper sources
g. Printed periodicals for popular magazine sources
h. Printed periodicals for scholarly article sources
i. Circulating books from the library
j. Reference books from the library
k. Course reserves 
1. Interlibrary loan

m. Link +

n. SJLibrary online catalog

o. Web site search engines (Please specify your favorites)

p. Web sites (Please specify your favorites)

q. Other (Please specify)

Comments (optional): 


\section{NEW SCHOLARLY BOOKS}

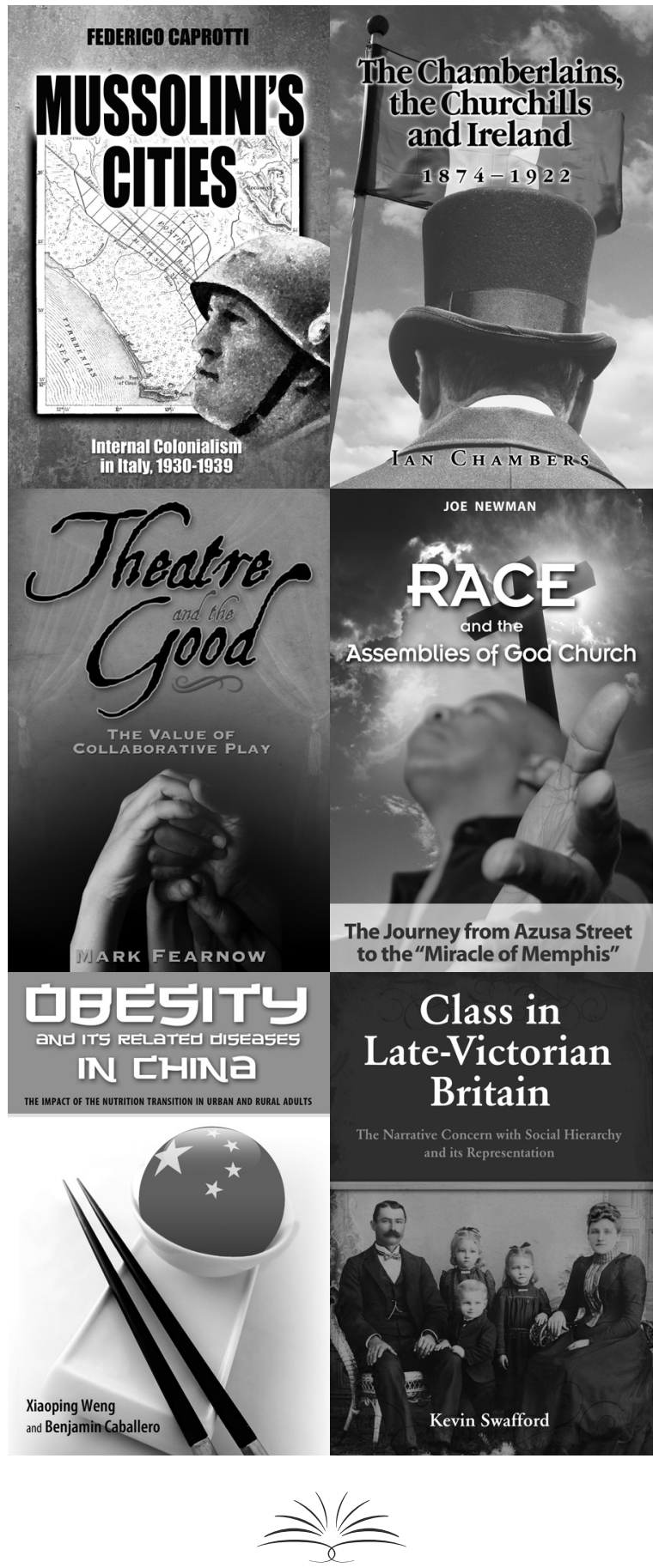

3

-

$\boldsymbol{\infty}$

$\boldsymbol{\infty}$

(a)

2

10

un

2

The Journey from Azusa Street to the "Miracle of Memphis"

ITS RELUTEU ㅁISEESES IN 대Nㅡㄹ

THE IMPACT OF THE NUTRTION TRANSTIION IN URBAN ANO RURAL ADUIIS

C A M B R I A

PRESS 